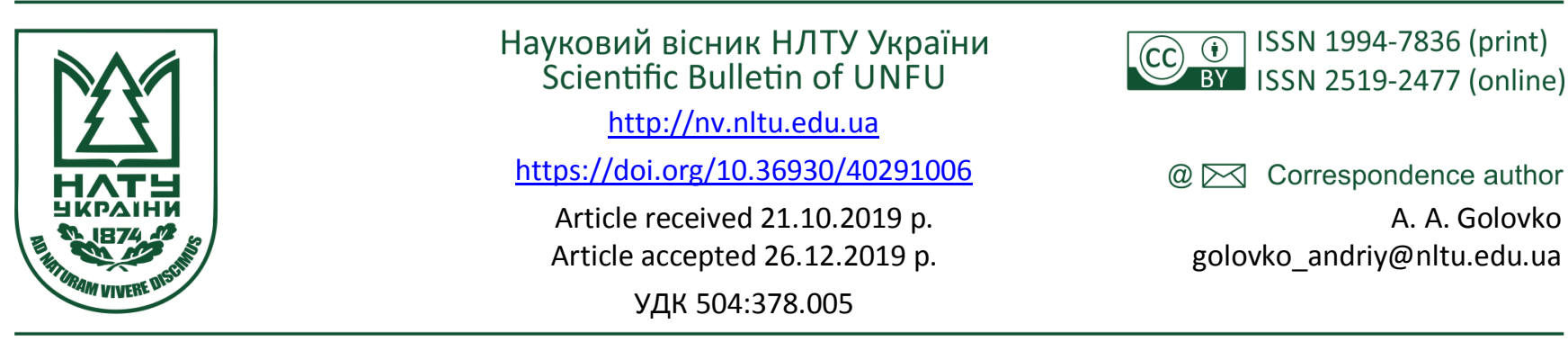

А. А. Головко, В. Р. Ковалишин, А. М. Польовський

Національний лісотехнічний університет Украйни, м. Львів, Украӥна

\title{
ЕКОЛОГІЗАЦІЯ МЕНЕДЖМЕНТ-ОСВІТИ УКРАЇНИ: ЗДОБУТКИ, ПРОБЛЕМИ, МОЖЛИВОСТІ
}

\begin{abstract}
Розглянуто проблематику введення екологічної складової у навчальний процес підготовки фахівців із менеджменту. Наголошено на важливості екологізації освітнього процесу на всіх рівнях освіти. Зокрема деталізовано потребу формування екологічного мислення фахівця з менеджменту за допомогою вивчення корпоративної соціальної відповідальності. Проаналізовано три основні групи компетентностей, зокрема: інтегральні, загальні та спеціальні (фахові, предметні) компетентності. Особливу увагу приділено екологічній компетентності, яка повинна бути наявна у всіх трьох групах компетентностей менеджера. Докладно розглянуто екологічну складову компетентностей студентів, котрі навчаються за магістерською освітньо-професійною програмою "Менеджмент організацій і адміністрування" у Національному лісотехнічному університеті України, зокрема в межах таких навчальних дисциплін, як: соціальна відповідальність, екологічна стандартизація і екологічна сертифікація, менеджмент природоохоронної діяльності, міжнародна екологічна політика, економіка лісокористування. Обгрунтовано потребу включення екологічних аспектів суспільної діяльності у процес формування освітніх програм фахівців із менеджменту.
\end{abstract}

Ключові слова: екологізація; освіта; менеджмент; екологічна компетентність.

Вступ. Менеджери - це фахівці, місія котрих полягає у тому, щоб формувати політику сталого розвитку підприємств та організацій. Менеджмент-освіта орієнтована на підготовку фахівців, відповідальних за управління персоналом та бізнес-процесами на всіх рівнях ієрархії у всіх сферах суспільної діяльності. Саме менеджери формують порядок денний підприємств та організацій. Тому цілком природно, що менеджери повинні бути обізнаними 3 тими глобальними викликами, котрі постають перед людством у XIX ст., та бути спроможними ухвалювати управлінські рішення, спрямовані на подолання цих викликів та гармонізацію стосунків між суспільством та довкіллям.

Варто відзначити, що на вищих рівнях управління системою освіти України існує розуміння необхідності екологізації освітнього процесу. На рівні шкільної освіти здійснюється практичні кроки щодо екологізації програм підготовки учнів. Учителі мають змогу пройти курси підвищення кваліфікації, спрямовані на формування розуміння сутності екологізації освітніх програм. Щодо екологізації вищої освіти, то на загальнодержавному рівні визнано потребу запровадження навчальної дисципліни "Корпоративна соціальна відповідальність" для студентів, котрі здобувають вищу економічну освіту.
Однак чи достатньо вивчення корпоративної соціальної відповідальності, щоб сформувати екологічне мислення фахівця 3 менеджменту? На сьогодні теорія і практика соціальної відповідальності зазнають критики через викривлене розуміння цього поняття бізнесструктурами. Соціальна відповідальність сприймається як індульгенція для дій, що не сприяють покращенню екологічного стану нашої планети. Соціальну відповідальність практикують компанії, які за визначенням не можуть бути соціально відповідальними. Адже, до прикладу, програми соціальної відповідальності, спрямовані на розвиток спорту, не можуть компенсувати шкоду, яку завдає суспільству виробництво тютюнових виробів чи алкогольних напоїв. Соціальні програми нафтових компаній не компенсують шкоди, завданої викидами парникових газів.

Очевидно, що фахівець 3 менеджменту повинен здобути такі компетентності, котрі б давали йому змогу чітко розуміти концепцію сталого розвитку та шляхи іiі впровадження на всіх рівнях менеджменту, розрізняти справжню соціально відповідальну діяльність організації та її імітацію (Karpenko, Mostoviak, \& Pushkareva-Bezdil, 2017). У процесі підготовки фахівця з менеджменту повинні формуватися не лише компетен-

\section{Інформація про авторів:}

Головко Андрій Андрійович, канд. екон. наук, доцент, завідувач кафедри менеджменту організацій та адміністрування. Email: golovko_andriy@nltu.edu.ua

Ковалишин Володимир Романович, канд. екон. наук, доцент, кафедра менеджменту організацій та адміністрування. Email: v_kovalyshyn@nltu.edu.ua

Польовський Андрій Михайлович, канд. екон. наук, доцент, кафедра менеджменту організацій та адміністрування. Email: a_polovsky@nltu.edu.ua

Цитування за ДстУ: Головко А. А., Ковалишин В. Р., Польовський А. М. Екологізація менеджмент-освіти України: здобутки, проблеми, можливості. Науковий вісник НЛТУ України. 2019, т. 29, № 10. С. 34-37.

Citation APA: Golovko, A. A., Kovalyshyn, V. R., \& Polovskyy, A. М. (2019). Ecologization of management-education in Ukraine: achievements, problems, possibilities. Scientific Bulletin of UNFU, 29(10), 34-37. https://doi.org/10.36930/40291006 
тності, спрямовані на розуміння сутності глобальних екологічних викликів та шляхів їх подолання, а і на формування особистих мотиваційних установок змінювати світ на краще.

Сучасні методичні підходи до формування освітньопрофесійних та освітньо-наукових програм передбачають формування трьох груп компетентностей (Qualifications, 2011; Rashkevich, 2014):

- інтегральна компетентність - узагальнений опис кваліфікаційного рівня, який виражає основні компетентністні характеристики рівня щодо навчання та/або професійної діяльності;

- загальні компетентності - універсальні компетентності, що не залежать від предметної галузі, але важливі для успішної подальшої професійної та соціальної діяльності здобувача в різних сферах та для його особистісного розвитку;

- спеціальні (фахові, предметні) компетентності- компетентності, що залежать від предметної галузі та є важливими для успішної професійної діяльності за певною спеціальністю.

У науковій літературі, що стосується методичних аспектів організації освітнього процесу, виділяють екологічну компетентність, тобто здатність особистості до ситуативної діяльності в побуті та природному оточенні, за якої набуті екологічні знання, навички, досвід i цінності актуалізуються в умінні приймати рішення, виконувати відповідні дії, нести відповідальність за прийняті рішення, усвідомлюючи іхні наслідки для довкілля [3]. Екологічна компетентність у діяльності менеджерів проявляється у розумінні процесів, що відбуваються у навколишньому середовищі та яким чином діяльність організації впливає на ці процеси. Екологічна компетентність повинна бути представлена у всіх трьох групах компетентностей, що формують освітньо-професійну чи освітньо-наукову програму підготовки фахівців 3 менеджменту.

Присутність екологічної складової в інтегральній компетентності повинна підкреслити важливість цього аспекту освітнього процесу та його нерозривний зв'язок з будь-якою сферою суспільної діяльності. Присутність екологічної складової серед загальних та спеціальних компетентностей дасть змогу сформувати знання, вміння та навики діяльності, що не приносить шкоди природі та допомагає адаптуватися до дії несприятливих чинників довкілля.

Певною мірою екологічна компетентність представлена у проектах освітніх стандартів для спеціальності 073 "менеджмент". Їі сформульовано у числі загальних компетентностей як "здатність діяти на основі етичних міркувань, соціально відповідально і свідомо" (Management, 2017). Однак, на наше переконання, екологічна складова повинна бути присутньою серед професійних компетентностей менеджера. Набір професійних компетентностей може змінюватись залежно від видів економічної діяльності, на які орієнтована та чи інша освітньо-професійна чи освітньо-наукова програма чи предметна сфера освітніх програм (наприклад менеджмент організацій і адміністрування, менеджмент зовнішньоекономічної діяльності). Однак орієнтовний їх перелік може бути таким:

- навички формування стратегій розвитку організацій на основі енергоефективних та безвідходних виробництв;
- здатність до сприяння розвитку екологічного мислення підлеглих шляхом відповідного застосування мотиваційних механізмів;

- розуміння сутності управління виробничою діяльністю, що не допускає негативного впливу організації на стан природних екосистем та ландшафтів;

- спроможність розвивати види діяльності, котрі сприятимуть зменшенню споживання природних ресурсів та розміщення продуктів діяльності в навколишньому середовищі;

- здібності планувати діяльність організації з урахуванням необхідності адаптації до глобальних змін клімату;

- спроможність сприяти відновленню деградованих під впливом антропогенної діяльності екосистем;

• розуміння процесів застосування відповідальних маркетингових технологій, що не стимулюють надмірне споживання;

• розуміння сутності концепції "зеленої" економіки (чи інших концепції, котрі сприяють впровадженню принципів сталого розвитку у практику економічної діяльності);

- формування системи управління, яка забезпечує постійне зниження вуглецевого сліду організації;

- здійснювати пошук нової парадигми розвитку, котра дала б змогу зменшити антропогенну присутність у природних екосистемах.

Екологічна складова компетентностей студентів, котрі навчаються за магістерською освітньо-професійною програмою "менеджмент організацій і адміністрування" у Національному лісотехнічному університеті України, формується у межах таких навчальних дисциплін:

- соціальна відповідальність;

- екологічна стандартизація і екологічна сертифікація;

• менеджмент природоохоронної діяльності;

- міжнародна екологічна політика;

• економіка лісокористування.

Зазначені дисципліни знаходяться у блоці вибіркових навчальних дисциплін, в такий спосіб студенти можуть сформувати необхідний набір екологічних компетентностей відповідно до їхнього бачення потенційного працевлаштування (McGonagil, 2017).

Навчальна дисципліна "соціальна відповідальність" покликана сформувати у студентів бачення соціальновідповідального управління організацією, що базується на концепції сталого розвитку та передбачає врахування екологічної, соціальної та економічної складових діяльності організації. У межах вивчення соціальної відповідальності студенти ознайомлюються 3 кращими практиками ведення соціально-відповідальної підприємницької діяльності та прикладами неправильного розуміння цієї концепції підприємцями. Студенти вивчають перелік критеріїв, які окреслюють сферу соціальної відповідальності організації і розроблені міжнародними організаціями, що ставлять за мету розвиток цієї концепції та розроблення стандартів щодо формування нефінансових звітів організацій. Студенти вивчають методичні підходи до формування концепції соціальної відповідальності організацій.

Прикладом забезпечення студентам спеціальних компетентностей є викладання дисципліни "Екологічна стандартизація і сертифікація". Ї̈і вивчення передбачає отримання таких компетентностей, як:

- можливості аналізу існуючих екологічних стандартів з метою вибору оптимального з них для впровадження у систему екологічного менеджменту підприємства; 
- прийняття управлінських рішень для забезпечення мінімізації негативного впливу виробництва на навколишнє середовище;

- удосконалення існуючих екологічних стандартів та підходів до проведення екологічної сертифікації шляхом впливу на прийняття рішень та участі в консультаційному процесі;

• розрахунок еколого-економічного ефекту від впровадження екологічного менеджменту на підприємстві та проведення екологічної сертифікації.

Викладання дисципліни здійснюється способом активного залучення студентів у процес лекційних та практичних занять. Зокрема застосовуються такі загальновідомі активні методи навчання, як: принцип "вулика"; робота з сусідом; інтерв'ю; робота з плакатом; дебати або дискусія "за і проти"; ділова гра. Використання цих методів допомагає активізувати розумовий i творчий потенціал студентів, додатково їх мотивувати, а також виробляє навики прийняття управлінських рішень та представлення себе і своїх думок.

Необхідно відзначити, що викладання дисциплін на кафедрі менеджменту організацій і адміністрування, до прикладу "Екологічної стандартизації та сертифікації", також можливе іноземною мовою, що сприятиме залученню іноземних студентів. Практика роботи в інтернаціональних навчальних групах свідчить про набуття студентами кращих комунікаційних навиків розширення світогляду та багажу знань завдяки спілкуванню 3 представниками різних соціальних та культурних груп з різних країн, запозиченню іноземного досвіду, вирішенню тих чи інших питань.

У межах вивчення дисципліни "Менеджмент природоохоронної діяльності" у студентів формується розуміння необхідності охорони природних екосистем від впливу антропогенної діяльності з метою збереження біологічного та генетичного різноманіття видів флори і фауни, що населяють ці екосистеми. До предмету вивчення дисципліни входить тематика ролі громадян та органів влади у формуванні та забезпеченні режиму охоронних територій. Студенти опановують методи переконання представників різних суспільних груп та прошарків населення у необхідності здійснення природозаповідної справи.

Процеси формування порядку денного щодо вирішення глобальних екологічних проблем людства входять до предмету вивчення навчальної дисципліни "Міжнародна екологічна політика". Навчальна дисципліна "Міжнародна екологічна політика" формує також розуміння інструментів, за допомогою яких можна досягнути цілі екологічної політики на міжнародному рівні. У процесі вивчення дисципліни студенти розуміють роль зацікавлених сторін, котрі визначають міжнародну екологічну політику. Важливою складовою цієї дисципліни є формування відповідної громадянської позиції у студентів та бажання особисто впливати на прийняття екологічно важливих рішень на локальному та глобальному рівнях.

Навчальна дисципліна "Економіка лісокористування" формує компетентності щодо економічного оцінювання різноманітних послуг лісових екосистем, що дає змогу перейти від сприйняття лісів як джерела деревних ресурсів до сприйняття лісів як складної екосистеми, котра, окрім деревини, надає суспільству корисні функції, такі як: водорегуляційна, кліматорегуляційна, протиерозійна, середовищетвірна тощо. Оцінювання екосистемних послуг лісових екосистем дає змогу простежувати зв'язок між належним функціонуванням природних екосистем та добробутом населення.

Окрім спеціальних дисциплін, що охоплюють певні аспекти екологічної компетентності, екологічна складова повинна бути присутньою у предметі кожної навчальної дисципліни. До прикладу, Келлі Макгонагіл у своїй книзі "Сила волі: шлях до влади над собою" проводить паралелі між здатністю людини досягати власні довгострокові цілі та неспроможністю відмовитися від діяльності, що руйнує екосистеми на глобальному рівні (Rashkevich, 2014). Тобто екологічна складова може бути включена до навчальних дисциплін, що вивчають теорію мотивації та самоменеджменту. Можна простежувати відповідні зв'язки між екологічною компетентністю та предметною сферою управління виробництвом, фінансовим менеджментом, маркетингом та іншими навчальними дисциплінами, що формують навчальний план студентів спеціальності "Менеджмент". Тому екологічні аспекти суспільної діяльності повинні бути в основі формування освітніх програм, щоб привертати увагу всіх викладачів, котрі забезпечують навчальні плани до необхідності включення екологічних аспектів до предмету дисциплін, що вони викладають.

\section{Висновки:}

1. Екологічні компетентності повинні бути присутніми в інтегральній, загальній та спеціальній частинах компетентностей фахівців з менеджменту.

2. Діяльність фахівця 3 менеджменту повинна бути орієнтованою на вирішення завдань організації з урахуванням обмежень, що накладають рамками природних екосистем та необхідністю адаптації до змін клімату.

3. Набуття спеціальних компетентностей забезпечують спеціалізовані дисципліни, зокрема: "Соціальна відповідальність", "Екологічна стандартизація і сертифікація", "Менеджмент природоохоронної діяльності", "Міжнародна екологічна політика", "Економіка лісокористування", що дають можливості розвитку та покращення системи екологічного менеджменту підприємства.

\section{References}

Karpenko, V. P., Mostoviak, I. I., \& Pushkareva-Bezdil, T. M. (2017). Assessment of the formation of environmental competencies. Odesa: NU "OMA", 59 p. [In Ukrainian].

Management. (2017). Draft higher education standard of the second (master) level of the field of knowledge 07 "Management and administration" of specialty 073 "Management". Retrieved from: https://mon.gov.ua/storage/app/media/vyshcha/naukovo-metodychna rada/proekty standartiv VO/073-menedzhment-magistr22.05.2017.docx. [In Ukrainian].

McGonagil, K. (2017). Power of will: the way to power over yourself. (Pavlenko I. Trans. From English). Kyiv: Our format, 264 p. [In Ukrainian].

Qualifications. (2011). National Framework of Qualifications, approved by the Resolution of the Cabinet of Ministers of Ukraine dated November 23, 2011, \#1341. Retrieved from: zakon2.rada.gov.ua/laws/show/1341-2011-п/paran12\#n12. [In Ukrainian].

Rashkevich, Yu. M. (2014). Bologna Process and New Paradigm of Higher Education. Lviv: Publishing Lviv Polytechnic, 168 p. [In Ukrainian]. 


\section{ECOLOGIZATION OF MANAGEMENT-EDUCATION IN UKRAINE: ACHIEVEMENTS, PROBLEMS, POSSIBILITIES}

Paper examines problems of including environmental component into educational process of management professionals. The importance of ecologization of the educational process on all levels of education is highlighted. The necessity of formation of environmental thinking of management professionals by studying corporate social responsibility is detailed, in particular. Three main groups of competencies are analysed. They are as follows: integral, general, and special (professional, subjective) competencies. Particular attention is drawn to environmental competency, which should be present in all three groups of managerial competencies. Environmental competence of managers should involve the understanding processes in environment and how the activity of the organization impacts these processes. In particular, strategy of the organization development should be based on energy efficiency and zero waste technologies; application of motivation to develop environmental thinking; understanding management of production to minimize negative impact on environmental ecosystems; development of activities, which would minimize natural resource consumption and waste disposal; planning the activity of organization considering global climate change; application of responsible marketing to minimize consumption patterns; understanding the concept of green economy and sustainable development; formation of the management system to minimize carbon footprint of the organization. The environmental component of students' competencies is considered in detail, particularly for Master educational-professional program "Management of Organizations and Administration" in Ukrainian National Forestry University, in particular within such educational disciplined as social responsibility, environmental standardization and environmental certification, management of nature conservancy, international environmental policy, and forestry economics. The necessity of integrating environmental aspects into the process of formation of the educational programs for management professionals is substantiated.

Keywords: ecologization; education; management; environmental competency. 